WSRC-MS-96-0384

CONF- $970113-4$

\title{
A Remotely Operated, Field Deployable Tritium Analysis System for Surface and Groundwater Measurement
}

by

K. J. Hofstetter

Westinghouse Savannah River Company

Savannah River Site

Aiken, South Carolina 29808

P. R. Cable

Westinghouse

SC USA

D. M. Boals

Westinghouse

SC USA

J. D. Jones

Westinghouse

SC USA

S. L Collins

Westinghouse

SC USA

J. E. Noakes

Center for Applied Isotope Studies

GA USA

J. D. Spaulding

Center for Applied Isotope Studies

GA USA

M. P. Neary

Conter for Appliad Isotope Studies

GA USA

R. Peterson

Sampling Systems, inc.

TX USA

DISTRIBUTION OF THIS DOCUMENT IS UNLIMITH

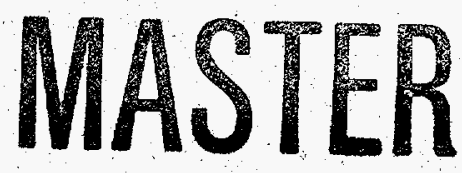

A document prepared for FIFTH INTERNATIONAL SYMPOSIUM ON FIELD ANALYTICAL METHODS FOR HAZARDOUS WASTES AND TOXIC MATERIALS at Las Vegas, NV, USA from 1/29/97 - 1/31/97.

DOE Contract No. DE-AC09-89SR18035

This paper was prepared in connection with work done under the above contract number with the U.S. Department of Energy. By acceptance of this paper, the publisher and/or recipient acknowledges the U.S. Government's right to retain a nonexclusive, royalty-free license in and to any copyright covering this paper, along with the right to reproduce and to authorize others to reproduce all or part of the copyrighted paper. 


\section{DISCLAMMER}

Portions of this document may be illegible in electronic image products. Images are produced from the best available original document. 


\section{DISCLATMER}

This report was prepared as an account of work sponsored by an agency of the United States Government. Neither the United States Government nor any agency thereof, nor any of their employees, makes any warranty, express or implied, or assumes any legal liability or responsibility for the accuracy, completeness, or usefulness of any information, apparatus, product, or process disclosed, or represents that its use would not infringe privately owned rights. Reference herein to any specific commercial product, process, or service by trade name, trademark, manufacturer, or otherwise does not necessarily constitute or imply its endorsement, recommendation, or favoring by the United States Government or any agency thereof. The views and opinions of authors expressed herein do not necessarily state or reflect those of the United States Govemment or any agency thereof.

This report has been reproduced directly from the best available copy.

Available to DOE and DOE contractors from the Office of Scientific and Technical Information, P.O. Box 62, Oak Ridge, TN 37831; prices available from (615) 576-8401.

Available to the public from the National Technical-Information Service, U.S. Department of Commerce, 5285 Port Royal Road, Springfield, VA 22161. 


\title{
A Remotely Operated, Field Deployable Tritium Analysis System for Surface and Ground Water Measurement
}

\author{
P. R. Cable, K. J. Hofstetter, D. M. Beals, J. D. Jones and S. L. Collins \\ Westinghouse Savannah River Company \\ Savannah River Technology Center \\ Aiken, SC 29808 \\ and \\ J. E. Noakes, J. D. Spaulding and M. P. Neary \\ Center for Applied Isotope Studies \\ 120 Riverbend $\mathrm{Rd}$. \\ Athens, GA 30602 \\ and \\ R. Peterson \\ Sampling Systems, Inc. \\ Drawer 567 \\ Old Ocean, TX 77463
}

\begin{abstract}
A prototype system for the remote, in situ analysis of tritium in surface and ground waters has been developed at the Savannah River Site through the combined efforts of university, private industry, and government laboratory personnel under a project funded by the U. S. Department of Energy. Using automated liquid scintillation counting techniques, the Field Deployable Tritium Analysis System (FDTAS) has been shown in laboratory and field tests to have sufficient sensitivity to measure tritium in water samples at environmental levels $(10 \mathrm{~Bq} / \mathrm{L}[\sim 270 \mathrm{pCi} / \mathrm{L}]$ for a 100 -minute count) on a near-real time basis. The FDTAS consists of a fixed volume sampler $(50 \mathrm{~mL})$, an on-line water purification system, and a stop-flow liquid scintillation counter for detecting tritium in the purified sample. All operations are controlled and monitored by a remote computer using standard telephone line modem communications. The FDTAS offers a cost-effective alternative to the expensive and time-consuming methods of field sample collection and laboratory analyses for tritium in contaminated groundwater.
\end{abstract}

\section{INTRODUCTION}

At the U. S. Department of Energy's Savannah River Site (SRS), a facility charged with the handling of tritium and other special nuclear materials, an estimated 24 million curies $(\sim 1 \mathrm{EBq})$ of tritium have been released to ground and surface waters from operational and disposal processes and from unplanned events (1). As one of the most widespread and mobile contaminants found on site, tritium poses a potential environmental hazard to populations in nearby communities and in the downstream Savannah River watershed. The management of high- and low-level wastes resulting from years of nuclear weapons production activities is now the highest priority mission of the U. S. Department of Energy while cleaning up the legacy of nuclear waste at the three production sites (SRS, Hanford and Oak Ridge). As a result, cutbacks in funding for environmental monitoring programs to track and control the release of radionuclides to waste streams have occurred.

The characterization of tritium in ground and surface waters at the SRS has been ongoing for many years by manual sample collection and laboratory analyses. Routine releases of tritium to surface streams have recently been monitored by the Tritium Effluent Water Monitors (TEWM), developed at SRS, $(\underline{2}, \underline{3})$ as well as by manual sampling and analyses. The TEWMs were developed as breakthrough monitors that detect tritium at high levels ( 1000 times normal background) for early notification of an 
unplanned release. The quantification of tritium released to the surface streams has been calculated exclusively from the sampling data, however. Present tritium contamination plume monitoring is accomplished by sampling monitoring wells, surface streams, and seeps.

While the removal of tritium from the contaminated ground and surface water is not feasible with present technology, other contaminants (e.g., volatile organic compounds (VOCs) like trichloroethylene (TCE), dense non-aqueous phase liquids (DNAPLs) like dodecane, inorganic metals like $\mathrm{Cd}, \mathrm{Pb}, \mathrm{Hg}$, etc.) are being removed by pump and treat processes at SRS. Air strippers are effectively removing many VOCs from contaminated groundwater at SRS. Ion exchange and reverse osmosis processes are now used to remove organic and inorganic contaminants in sub-surface aquifers. In most cases, the chemically purified water is either released to surface streams or pumped back into the subsurface ground water. Except for occasional minor dilution, the tritium concentration remains unchanged during these processes. Regulations require measurement of tritium concentrations before and after treatment on a rigorous sampling frequency. There is also a concern about opening new pathways for nuclide migration when pumping from and to an existing aquifer.

Because the analyses for tritium in contaminated groundwater is time-consuming and expensive, a project was funded by the U. S. Department of Energy to develop a remotely operated, field deployable tritium analysis system for use in the DOE complex. With present day advancements in computers, remote communication technologies, and low-background radiation detection systems, it was felt that the necessary components were in place to develop an automated system for measuring tritium at environmental levels for near real time monitoring of potential and existing contaminant plumes. Scientists and engineers from the Center for Applied Isotope Studies (CAIS) at the University of Georgia, Sampling Systems Inc., and Westinghouse Savannah River Company entered into a cooperative agreement to develop the FDTAS under DOE sponsorship. A prototype unit has been developed for making remote, near real-time, in situ measurements of tritium concentrations in surface and ground water samples. The FDTAS has sufficient detection sensitivity to measure tritium in water samples at environmental levels and will be applied at the SRS for waste site and risk assessment, field monitoring and screening, and state and federal environmental compliance activities. It has been designed for remote control with multi-site sampling and data retrieval capabilities, and may be automated for on-demand or unattended operation. The FDTAS is presently undergoing rigorous field testing at monitoring well sites and lake and river sampling locations at the SRS.

\section{DESCRIPTION}

The prototype FDTAS consists of several major components: a multi-port, fixed volume sampler, an on-line water purification system using single-use "tritium columns", a tritium detector employing liquid scintillation counting techniques, and the serial communications devices. The sampler and water purification system, referred to as the "autosampler", is controlled by a Programmed Logic Controller (PLC) pre-programmed to perform a well defined sampling, purification and flushing protocol. The tritium analyzer is controlled by custom software in the local computer for mixing the purified sample with liquid scintillation (LS) cocktail, counting, and flushing the cell. An external standard is used to verify system performance and for quench correction. All operations are initiated and monitored at the remote computer through standard telephone line modem communications. A block diagram of the various components is shown in Figure 1.

\section{Autosampler}

Researchers at the Savannah River Technology Center, in cooperation with Sampling Systems, Inc. developed a fully programmable, remotely operated, fixed volume, automatic sampler for use with the tritium analyzer. The autosampler is designed to collect $50 \mathrm{~mL}$ water samples on-demand from up to 8 different sampling locations. By limiting the sample volume, minimum quantities of radionuclides or other contaminants are removed from the source which reduces the amount of waste generated by the analysis process. The sampling apparatus pre-filters the water with a 70 -micron size-exclusion frit, 
prior to introduction to the on-line purification system. The anions, cations, and organic impurities in the sample are then removed by passing through a commercially available, water purification column. Up to 32 sealed "tritium columns" are housed in a pneumatically actuated carousel. The tip of an unused column is first broken off and the $50 \mathrm{~mL}$ aqueous sample is injected through a septum in the top at a flow rate of $\sim 5 \mathrm{~mL}$ per minute. The first $20 \mathrm{~mL}$ aliquot of eluent is automatically discarded as being non-representative, and a subsequent $20 \mathrm{~mL}$ fraction is delivered to a sample reservoir equipped with a capacitive level-sensing device. The remainder of the eluent is automatically diverted to waste. Once the meniscus sensing apparatus is triggered, an output signal is sent to the tritium analyzer, which then prompts a valve/pumping sequence to transfer the purified sample to the counting cell for liquid scintillation counting. The autosampler is then flushed with deionized water and purged with air, once the tritium analyzer begins its analysis sequence. Micro-bore tubing is used throughout the system to minimize holdup and cross contamination. The autosampler may act as a stand-alone device, and is enclosed in a rugged, field-portable case equipped with wheels for ready transport. It weighs approximately 40 pounds. Figure 2 shows a schematic of the autosampler.

\section{Tritium Analyzer}

A Packard Radiomatic 525TR liquid scintillation counter was selected as the basic instrument for low-level tritium measurements but was extensively modified by scientists at CAIS in order to meet the required sensitivities. To accommodate measurement of the low levels of tritium in aqueous environmental samples, a special quartz cell was developed to increase the aqueous volume to $\sim 5 \mathrm{~mL}$ and permit measurements on a stop/flow basis; the 525TR was designed for continuous flow measurements. The reduction of background was also critical in achieving the required sensitivity. This was accomplished by redesign of the counting chamber and sample vial holder, increased lead shielding, and the incorporation of $\mathrm{Bi}_{4} \mathrm{Ge}_{3} \mathrm{O}_{12}$ (bismuth germanate, $\mathrm{BGO}$ ) windows in the counting chamber, coupled with after-pulse counting electronics. This dual-scintillator technique has been shown to be effective in reducing backgrounds in liquid scintillation counting systems (4).

The prototype FDTAS is enclosed in a field-portable steel housing containing additional lead shielding. The redesigned counting chamber is made of high-purity electrolytic copper that is coated on the interior with a white reflective paint to enhance photon collection by the photomultiplier tubes. The chamber accommodates a specially designed $\sim 10 \mathrm{~mL}$ flow-through quartz sample vial of $8 \mathrm{~mm}$ thickness and $40 \mathrm{~mm}$ diameter. A pair of $6 \mathrm{~mm}$ thick BGO windows are incorporated into the counting chamber for background reduction and bracket both sides of the quartz sample vial. The counting chamber, quartz vial, and BGO window configurations were optimized through a series of laboratory tests and optical modeling software.

\section{System Control}

To accommodate computer-automated sequencing of remotely collected samples, a sample collection and injection system was assembled using solenoid valves, metering pumps, and flow controllers. All operations on the autosampler are conducted pneumatically using a combination compressor/vacuum pump. The sequencing of valves, and monitoring of level indicators, flow meters, and pressure switches in the autosampler are controlled by the PLC. In the tritium analyzer, the flow system is controlled by a 24-channel relay accessory board and parallel I/O board in the local computer. The software for spectral data acquisition and analysis is the standard Packard FLO-ONE code for the 525TR system. Both components (autosampler PLC and Packard 525TR tritium analyzer) are controlled and monitored by custom software operating in WINDOWS 3.1 which permits the collection of samples from multiple sites, computer automated sequencing of sample injection, cocktail mixing, sample counting, sample outflow and system flushing and cleaning.. Two-way communications with the autosampler and tritium analyzer is accomplished along a single telephone line using a 9600 baud modem with multiplexed inputs from both systems. 


\section{EXPERIMENTAL}

The commercially available "tritium columns" (EIChroM Industries, Inc.), containing about 2 cc of three distinct types of absorbing material, were tested for their applicability to automated use in the proposed autosampler. The columns are designed to remove the matrix elements from solution, resulting in a column effluent similar to a sample that had been prepared for tritium analysis by distillation. Capacity studies showed that column performance did not significantly degrade with sample volumes up to $50 \mathrm{~mL}$, even when starting with a seawater matrix saturated with chlorinated hydrocarbons, under gravity flow conditions (about $0.5 \mathrm{~mL} /$ minute). At flow rates greater than 10 $\mathrm{mL} / \mathrm{minute}$, however, some break through of matrix ions was evident. A flow rate of $5 \mathrm{~mL} / \mathrm{minute}$ was thus chosen as optimum for column performance and sample throughput. As the resin columns are shipped from the manufacturer in water, the first several milliliters of sample eluting from the column is somewhat diluted. Laboratory studies showed that an equilibrium was established after $15 \mathrm{~mL}$ of sample had passed through the column. It was therefore decided to discard the initial $20 \mathrm{~mL}$ of sample through the column to avoid the dilution effect. A typical tritium analysis operation requires $5 \mathrm{~mL}$ of sample so that several duplicate analyses can be run from a single $50 \mathrm{~mL}$ sample.

A variety of LS cocktails, including Packard Ultima Gold LLT, Ultima Gold AB, Ultima Gold $\mathrm{XR}$, and Ultima Flo $\mathrm{M}$ were evaluated for use with the FDTAS. In addition to the parameters of background and counting efficiency, the viscosity of the cocktail also required consideration. Sample backgrounds were determined using a Packard 2550 LS counter. The cocktails were spiked with a known aliquot of known tritium activity and then counted to determine counting efficiency. The Ultima Gold LLT, normally a clear choice for tritium counting due to its low background and high efficiency, was found to be too viscous to be readily washed from the sample vial during the cleaning cycle. Two other viscous cocktails, Ultima Gold XR and Ultima Flo $M$ were found to have a significantly higher background and low counting efficiency when compared with Ultima Gold AB. Although the Ultima Gold $A B$ has a high viscosity, it could be washed out of the vial using methanol and was chosen as the best cocktail for this application. Using Ultima Gold AB, a series of tests were performed to determine the optimum water to cocktail ratio. Cocktail:water mixtures of 40:60, 50:50, 60:40, and 70:30 were made up and counted to determine the backgrounds. The mixtures were then spiked with a know tritium activity and then recounted to determine the tritium detection efficiency. The 50:50 cocktail:water ratio was found to produce the best overall results for the FDTAS measurements.

Many tests were conducted to maximize the efficiency of the autosampler and flow-cell flushing operations to optimize the cleaning cycle, minimize the amount and type of waste, and minimize cross contamination of samples. Cleaning of the autosampler is accomplished with non-tritiated water flushes and air purges of the lines. For the tritium analyzer, various alcohol solvents were tested with methanol found to produce the best cleaning results. Three washes of pure methanol, followed by three washes of non-tritiated water serve to completely eliminate any "memory" in the system. Bubbling air through the cell was found to be a necessary step in the cleaning operation.

\section{TESTING AND EVALUATION}

The remote testing of the tritium analyzer capabilities was first conducted in the CAIS laboratory in March 1996. The remote computer was set up in one laboratory and the tritium analyzer and local computer, which included the valve control interface, were located in a separate laboratory. Using a telephone/modem linkage, the sample collection/analysis/cleaning cycle was successfully operated from the remote computer. A background of $1.35 \mathrm{cpm}$ and a counting efficiency of $24 \%$ were demonstrated in this laboratory setting. These data yield a minimum detectable activity (MDA) of $\sim 7.2 \mathrm{~Bq} / \mathrm{L}$ at the $95 \%$ confidence level for a 100 -minute count via the method of Currie (5).

A preliminary field test was conducted at the SRS in May 1996 which was similarly successful. The tritium analyzer was placed in a small trailer equipped with a motor generator and located near LLake, a man-made lake constructed in 1985 to receive the heated secondary coolant from one of the five production reactors at the SRS. The L-Lake sampling location is about $17 \mathrm{~km}$ from the central 
laboratory where the remote computer was stationed. Remote communications were established between the laboratory and the field site using a telephone line and the modem. Using the remote computer, the tritium analyzer was instructed to take an aqueous sample, acquire and analyze the spectrum, evaluate background, empty and cleanse the sample vial in preparation for the next sample cycle. A background of $1.469 \mathrm{cpm}$ and a counting efficiency of $23.9 \%$ were demonstrated in the field, which results in a low MDA for a 50 -minute count $(\sim 10.1 \mathrm{~Bq} / \mathrm{L})$. For this test, the aqueous samples collected were introduced directly into the tritium analyzer after manually purifying the sample through an EIChroM resin column. An aliquot of the aqueous sample was returned to the laboratory for confirmatory analysis using a Quantulus $1220 \mathrm{LS}$ counter. Table 1 presents a comparison of the results from the field tests and the laboratory measurements which demonstrates good agreement. (Note: the laboratory sample was approximately twice the volume of the field sample, resulting in a lower MDA for the 50-minute count).

A second field test was performed at the SRS in June 1996 where TCE was being removed from groundwater by air stripping. A background of $1.5 \mathrm{cpm}$ and a counting efficiency of $27 \%$ was observed during these tests. As before, the water samples were treated manually with the EIChroM resin columns before analysis. Parallel samples were returned to the laboratory for confirmatory analyses. Table 1 shows that the field analyses during these experiments are also in good agreement with the laboratory analyses with no detectable bias.

\section{CONCLUSIONS}

A remotely operated system has been developed to collect a limited-volume sample and perform on-line sample purification for tritium analyses from multiple collection sites. A one-step purification system was developed to remove all impurities which interfere with the tritium analysis by liquid scintillation counting. Limited field testing has confirmed the operation of the system. Additional field testing of the entire system, including sample delivery and purification is scheduled for early 1997.

The development of a prototype system for the field analysis of tritium in ground and surface waters has been accomplished at the Savannah River Site. All requirements for a remotely operated, multi-port, 2-man portable, field deployable tritium analysis system have been met which measures tritium at environmental levels in near real-time. Using automated water purification and liquid scintillation counting techniques, the FDTAS has been shown to detect tritium at $\sim 10 \mathrm{~Bq} / \mathrm{L}$ concentrations within 2 hours of sampling (100 minute count) with minimum associated derived wastes. Detection limits at $25 \mathrm{~Bq} / \mathrm{L}$ levels can be met with a 10 minute count. These limits are well below the EPA drinking water standard for tritium at $740 \mathrm{~Bq} / \mathrm{L}(\underline{6})$ and lower than the normal upstream Savannah River tritium concentration of $\sim 40 \mathrm{~Bq} / \mathrm{L}$ ( 7 ).

The use of the FDTAS for selective, on-demand, rapid analysis of ground and surface water samples eliminates the need for costly routine sample gathering and lengthy laboratory analyses that are presently used for monitoring wells, rivers, streams and seeps. The mobility of the field units and possible multiple units controlled by a central processor suggests the FDTAS can be used for many applications. The SRS prototype will be extensively tested under a variety of field conditions and fieldhardened for optimum performance. Commercialization of the technology is presently under consideration.

\section{REFERENCES}

1. Murphy, C. W., Jr., Hayes, D. W., Marter, W. L., Ziegler, C. C., Stephenson, D. E., Hoel, D. D., and Hamby, D. M.; Tritium in the Savannah River Site Environment, WSRC-RP-90-424 Rev. 1, Westinghouse Savannah River Company, May 1991.

2. Hofstetter, K. J. and Wilson, H. T., Fusion Technology 1992 21, (2), 446-451.

3. Hofstetter, K. J., Fusion Technology $1995 \underline{28}$, (3), 1527- 1531 
4. John E. Noakes and Robert J. Valenta, "An $\alpha / \beta / \gamma$ Liquid Scintillation Counter Using $\mathrm{Bi}_{4} \mathrm{Ge}_{3} \mathrm{O}_{12}$ as an Auxiliary Scintillator", in Proceedings of the International Conference on Advances in Liquid Scintillation Spectrometry, LSC'94: Glasgow, Scotland, August 1994.

5. Currie, L. A., Analytical Chemistry 1968 40, (3), 586-693.

6. Code of Federal Regulations, "National Primary Drinking Water Regulations", 40CFR, Part 141, Washington DC, pp. 526-575, (1987).

7. Environmental Monitoring in the Vicinity of the Savannah River Plant. Annual Reports (197883), SRP 1978-83, E. I. duPont de Nemours and Company, Inc., Savannah River Plant, Aiken, $\mathrm{SC}$.

\section{ACKNOWLEDGMENTS}

The authors are indebted to Ron Johnson of the Environmental Technology Section of SRTC for the countless hours of work in support of the field tests at SRS and to Craig Peterson, Doug Hampton, and Vic Heath at Sampling Systems, Inc. for their continuing development of the autosampler and communication devices. The information contained in this document was developed during the course of work done under Contract No. DE-AC09-89SR18035 with the U. S. Department of Energy.

Table 1. Field and laboratory data comparison.

\begin{tabular}{|c|c|c|c|c|c|c|c|}
\hline Instrumentation & $\begin{array}{c}\text { Sample } \\
\text { Description }\end{array}$ & $\begin{array}{l}\text { Vol } \\
(\mathrm{mL})\end{array}$ & $\begin{array}{l}\mathrm{MDA} \\
(\mathrm{Bq} / \mathrm{L})\end{array}$ & $\begin{array}{l}\text { Gross } \\
\text { CPM }\end{array}$ & $\begin{array}{c}\text { Background } \\
\text { CPM }\end{array}$ & $\begin{array}{l}\text { Counting } \\
\text { Efficiency }\end{array}$ & $\begin{array}{r}\text { Activity } \\
(\mathrm{Bq} / \mathrm{L})\end{array}$ \\
\hline FDTAS & L-Lake & 5.5 & $10.13^{1}$ & 31.24 & 1.469 & 0.239 & 377.5 \\
\hline Quantulus & L-Lake & 10.1 & $5.48^{1}$ & 56.47 & 1.47 & 0.243 & 377.2 \\
\hline FDTAS & Air-Stripper & 5.5 & $6.41^{2}$ & 25.47 & 1.50 & 0.27 & 269.0 \\
\hline Quantulus & Air-Stripper & 5.5 & $4.70^{2}$ & 28.64 & 1.35 & 0.35 & 236.9 \\
\hline
\end{tabular}




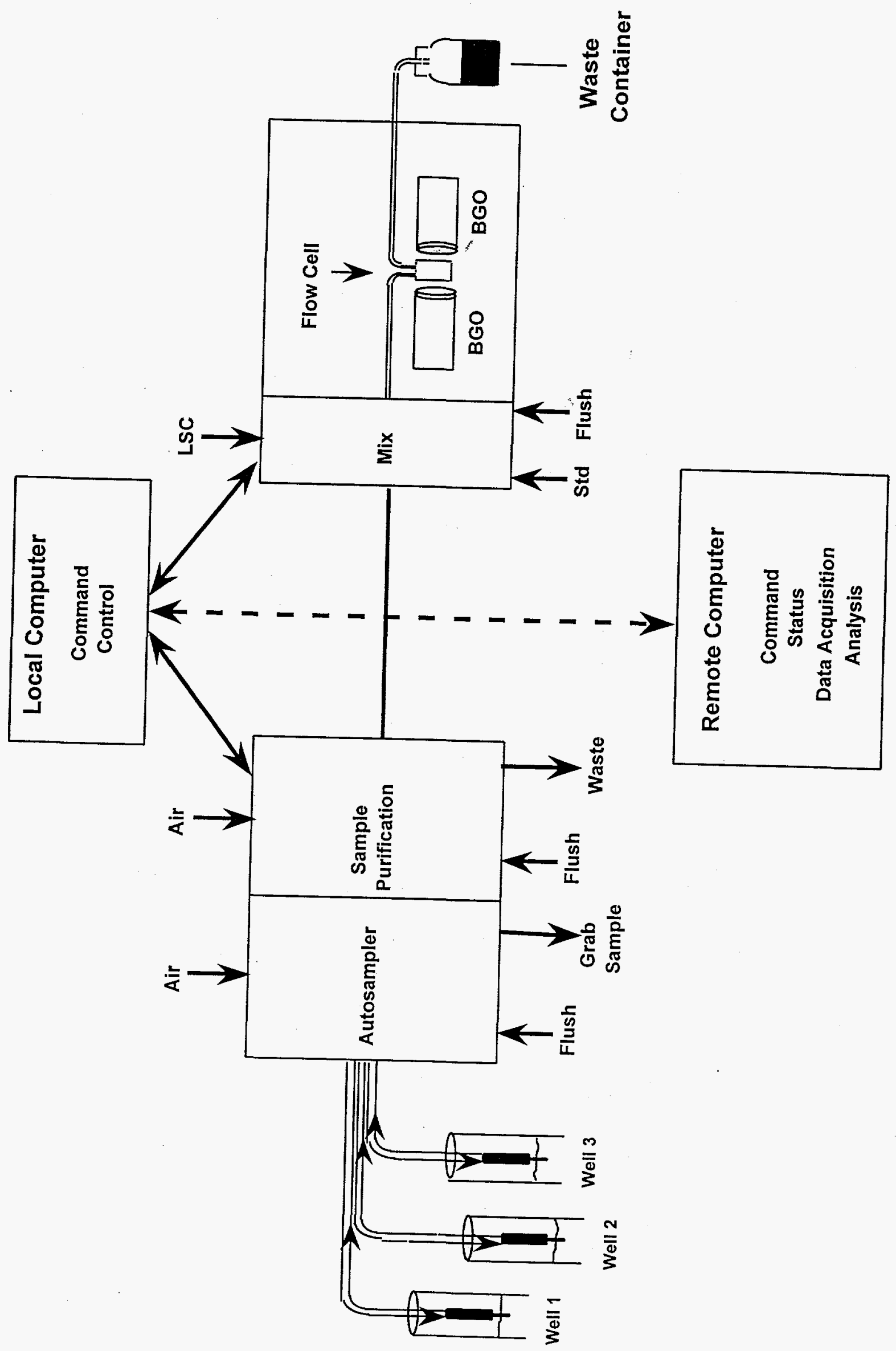




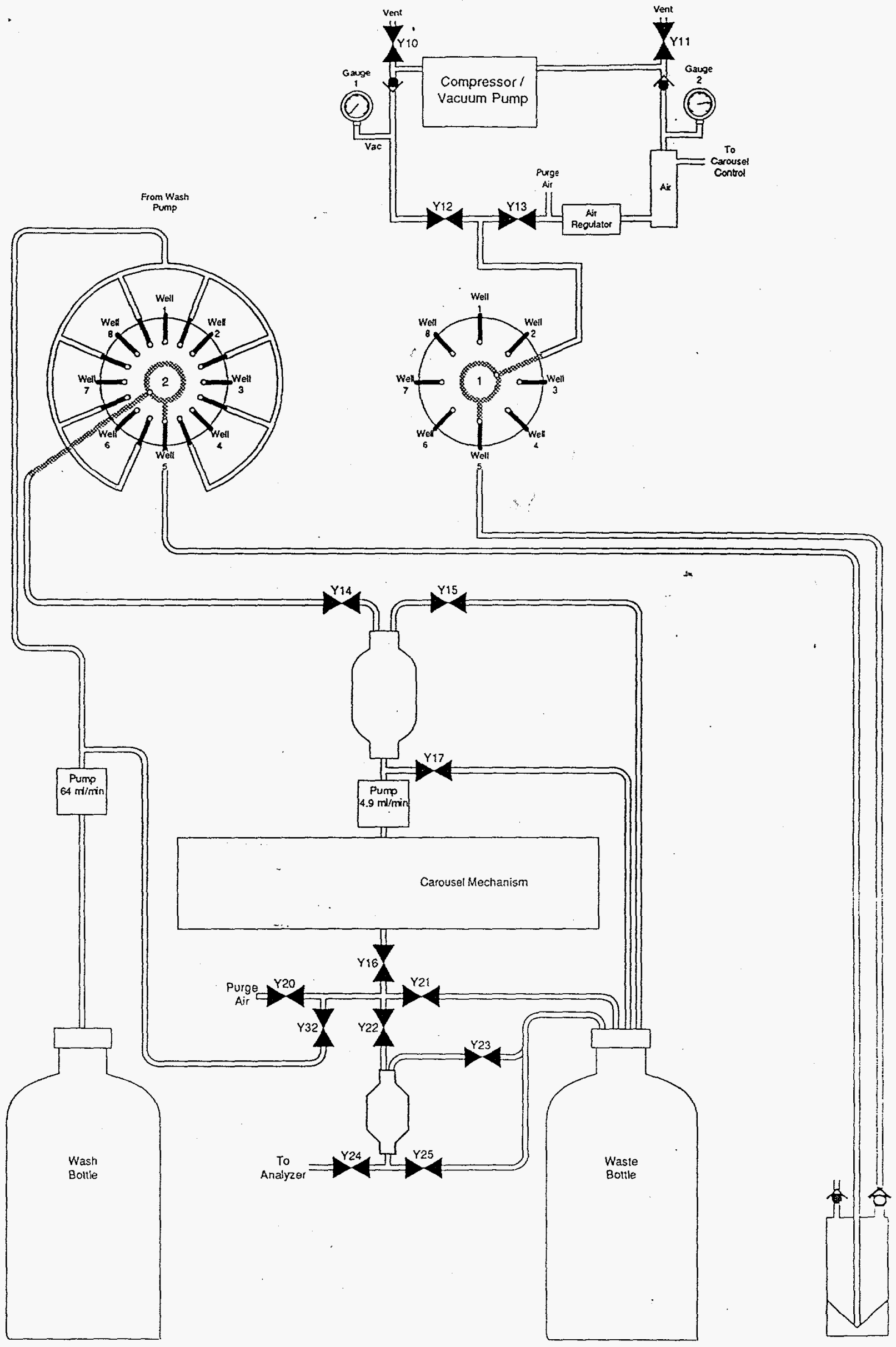

